\title{
Survival, Virulent Characteristics, and Transcriptomic Analyses of the Pathogenic Vibrio anguillarum Under Starvation Stress
}

\author{
Xiaojian Gao, Daming Pi, Nan Chen, Xixi Li, Xiaodan Liu, Hui Yang, Wanhong Wei and \\ Xiaojun Zhang* \\ College of Animal Science and Technology, Yangzhou University, Yangzhou, China
}

\section{OPEN ACCESS}

Edited by:

Margaret E. Bauer,

Indiana University School of Medicine,

United States

Reviewed by:

Lluis Tort,

Autonomous University of Barcelona,

Spain

Sucharit Basu Neogi,

International Centre for Diarrhoeal Disease Research (ICDDR),

Bangladesh

*Correspondence:

Xiaojun Zhang zxj9307@163.com

Specialty section:

This article was submitted to Molecular Bacterial Pathogenesis,

a section of the journal

Frontiers in Cellular and Infection

Microbiology

Received: 21 April 2018 Accepted: 15 October 2018 Published: 16 November 2018

Citation:

Gao X, Pi D, Chen N, Li X, LiU X, Yang $H$, Wei $W$ and Zhang $X$ (2018) Survival, Virulent Characteristics, and

Transcriptomic Analyses of the

Pathogenic Vibrio anguillarum Under Starvation Stress.

Front. Cell. Infect. Microbiol. 8:389. doi: 10.3389/fcimb.2018.00389
Many bacteria have developed strategies for metamorphosis into sophisticated survival forms to survive extended periods of environmental stress. As a global causative agent of vibriosis in marine fish farming, Vibrio anguillarum ( $V$. anguillarum) can efficiently grow and proliferate under environmental stress, but the specific mechanism is not clear. In the present study, survival, virulent characteristics, and transcriptomic analysis of the $V$. anguillarum $\mathrm{BH} 1$ were performed under starvation stress. The results demonstrated that $V$. anguillarum was still culturable and showed rippled surface after 6 months of starvation. Starved cells maintained their infectivity in half-smooth tongue sole (Cynoglossus semilaevi). Detection of virulence factors and virulence-associated genes in starved cells showed that the starved strain still produced $\beta$-hemolysis on rabbit blood agar, caseinase, dnase, and gelatinase, and possessed empA, vah1, vah2, vah3, vah4, vah5, rtxA, flaA, flaD, flaE, virC, ton $\mathrm{B}$, mreB, toxR, rpoS, and ftsZ virulencerelated genes. In addition, we first reported the RNA-seq study for $V$. anguillarum with and without starvation treatment for a period of 6 months and emphasized the regulation of gene expression at the whole transcriptional level. It indicated that $V$. anguillarum expressed 3,089 and 3,072 genes in the control group and starvation stress group, respectively. The differently expressed genes (DEGs) of the starved strain were thereby identified, including 251 up-regulated genes and 272 down-regulated genes in comparison with the non-starved strain. Gene Ontology (GO) analysis and Kyto Encyclopedia Genes and Genomes (KEGG) enrichment analysis of DEGs were also analyzed. GO functional classification revealed that among the significantly regulated genes with known function categories, more genes affiliated with signal transducer activity, molecular transducer activity, and cell communication were significantly upregulated, and more genes affiliated with cellular macromolecule, cellular component, and structural molecule activity were significantly down-regulated. In addition, the DEGs involved in the pathway of two-component system was significantly up-regulated, and the pathways of ribosome and flagellar assembly were significantly down-regulated. This study provides valuable insight into the survival strategies of $V$. anguillarum and suggests that a portion of the bacterial populations may remain pathogenic while persisting under starvation stress by up-regulating or down-regulating a series of genes.

Keywords: Vibrio anguillarum, starvation, survival, virulent characteristics, transcriptome sequencing 


\section{INTRODUCTION}

Vibrio anguillarum is a gram-negative bacterium causing vibriosis in fish and shellfish species, and is widely distributed in marine and estuarine environments around the world (Toranzo et al., 2005; Kim et al., 2012; Ma et al., 2017). Fish infected by $V$. anguillarum showed typical signs of a generalized septicemia with hemorrhage on the base of fins, exophthalmia, and corneal opacity (Frans et al., 2011). It has brought enormous economic losses to aquaculture businesses due to the wide range of $V$. anguillarum infections among the aquaculture species including Atlantic salmon (Salmo salar), rainbow trout (Oncorhynchus mykiss), sea perch (Dicentrarchus labrax), ayu (Plecoglossus altivelis), Atlantic cod (Gadus morhua), puffer fish (Takifugu rubripes), and manila clam (Ruditapes philippinarum) (Rodkhum et al., 2005; Mikkelsen et al., 2007; Higuera et al., 2013; Álvarez et al., 2016; Nie et al., 2017; Ren et al., 2017; Liu et al., 2018). Due to the great losses caused by $V$. anguillarum to the aquaculture industry, more attention has been paid extensively to the research regarding this opportunistic pathogen.

Nutrient insufficiency is one of the most common environmental stresses which bacteria routinely encounter in natural ecosystems. Similar to many other marine bacteria, Vibrio spp. have been observed to survive for a long period during starvation by sequential changes in cell physiology and gradual changes in morphology. The reduction in size, e.g., rod-shaped bacteria turning into coccoid, is beneficial to minimize the requirements for cell maintenance and adapt to environmental stresses (Chen et al., 2009). Many reports have demonstrated that $V$. cholerae, $V$. vulnificus, $V$. parahaemolyticus, and $V$. alginolyticus could enter into a viable but non-culturable stage when exposed to a low-nutrient environment (Jiang and Chai, 1996; Mcdougald et al., 1998; Chaiyanan et al., 2007; Amel et al., 2008; Abdallah et al., 2010; Su et al., 2013). Besides, under such changing environmental conditions, the metabolic pathways of bacteria would be altered to maintain their cellular functions. Vibrio anguillarum could persist under conditions of carbon starvation for a long period (Fujiwara-Nagata and Eguchi, 2004). Eguchi et al. reported that starvation of infective $V$. anguillarum induced a reduction in growth and pathogenicity and led to a change in shape from a short rod to a spherical microcell (Eguchi et al., 2000). Larsen et al. observed that $V$. anguillarum was chemotactic to serine in the temperature range $5-25^{\circ} \mathrm{C}$ and in $0.8-2.7 \% \mathrm{NaCl}$, and also showed a high chemotactic response after starvation (Larsen et al., 2004). Vibrio anguillarum may also develop bile salt resistance through biofilm formation while persisting within intestinal environment (Wang et al., 2003). In addition, some studies have demonstrated that environmental stress could affect the expression of virulence genes in $V$. anguillarum that have implications on the competitiveness, stress tolerance, and the ability of $V$. anguillarum to cause infection (Crisafi et al., 2014). Therefore, it is important to study the gene expression of microorganisms in order to understand the pathogenicity and molecular adaptations of microorganisms under environmental stress.

In this study, we focused on the changes of the morphology, survival, and virulent characteristics of $V$. anguillarum $\mathrm{BH} 1$ induced by starvation. The full transcriptome of $V$. anguillarum BH1 strain during starvation stress using high-throughput sequencing was also analyzed. The present study will provide foundations to have a better understanding of virulence and survival mechanism of the bacterium under extreme environmental conditions.

\section{MATERIALS AND METHODS}

\section{Bacterial Strains and Starvation Stress}

$V$. anguillarum strain $\mathrm{BH} 1$ was originally isolated in our lab from diseased half-smooth tongue sole (C. semilaevi) which caused mass mortalities of cultured half-smooth tongue sole in a farm in Ganyu County of Jiangsu Province, China. It was stored in $2216 \mathrm{E}$ marine broth supplemented with $10 \%$ glycerol frozen at $-80^{\circ} \mathrm{C}$ in our lab, and routinely cultured on $2216 \mathrm{E}$ marine agar at $28^{\circ} \mathrm{C}$ for $16 \mathrm{~h}$. The bacterial colony from the strain was inoculated into $100 \mathrm{~mL}$ of $2216 \mathrm{E}$ marine broth and incubated at $28^{\circ} \mathrm{C}$ for $16 \mathrm{~h}$ while being shaken. Vibrio anguillarum cells were collected by centrifugation at $8,000 \times \mathrm{g}$ for $10 \mathrm{~min}$ at $4^{\circ} \mathrm{C}$ and washed twice with sterile saline solution $(0.9 \% \mathrm{w} / \mathrm{v} \mathrm{NaCl})$. The cells were then inoculated into sterile Erlenmeyer glass flasks $(300 \mathrm{~mL})$ containing $100 \mathrm{~mL}$ of sterile saline to a concentration of $\sim 10^{9}$ $\mathrm{CFU} / \mathrm{mL}$. Three repetitions of microcosms were incubated in a static state at $28^{\circ} \mathrm{C}$ as starvation treatment group, i.e., without any nutrient supplement added periodically, and monitored for a period of 6 months. The freshly prepared log-phase $V$. anguillarum cell culture without starvation treatment was used as the control.

\section{Ultrastructural Analysis}

Morphological changes between 6-months starved and nonstarved cells were observed under a scanning electronic microscope (SEM) as previously described with minor modification (Arias et al., 2012). Briefly, $10 \mu \mathrm{L}$ of bacteria was fixed in $2.5 \%$ glutaraldehyde $(\mathrm{v} / \mathrm{v})$ on $8 \times 8 \mathrm{~mm}$ glass slides at $4{ }^{\circ} \mathrm{C}$ overnight. Then, samples were dehydrated in a graded ethanol series (50,70, 90, and 100\%), coated with gold palladium alloy in an EMS 550X (Electron Microscopy Science), and examined under Zeiss EVO 50 electronic microscope (Zeiss, Germany).

\section{Viability Measure}

The viability of $V$. anguillarum was measured at 1, 2, 3, 4, and 6 months post-inoculation. $100 \mu \mathrm{L}$ of samples were serially 10 -fold diluted in sterilized distilled water and were plated on LB agar in triplicate. The number of CFU were expressed as the mean \pm standard deviation (SD).

\section{Bacterial Motility Test}

The motility of $V$. anguillarum BH1 was measured after $0,1,2$, $3,4,5$, and 6 months starvation. Bacterial motility testing was performed as described previously (Xu et al., 2014). Briefly, the $V$. anguillarum cells in TSB, which had reached the early stationary phase, were separately spread on TSA supplemented with $1.5 \%$ agar. The plates were incubated at $28^{\circ} \mathrm{C}$ until formation of the colonies. A single colony from plates supplemented with $1.5 \%$ 
agar was inoculated by a puncture in the middle of the plates containing $0.4 \%$ agar. The diameter of the halo surrounding the punctured portion of the agar media was measured $24 \mathrm{~h}$ post-inoculation.

\section{Determination of Extracellular Enzymes and Hemolysin of Starved Cells}

The presence of caseinase, gelatinase, lipase, lecithinase, dnases, and hemolysin of the 6-months starved cells were determined by directly streaking the starved cells onto $2216 \mathrm{E}$ nutrient agar that contained $8 \%$ gelatin (gelatinase test), 1\% Tween-80 (lipase test), $10 \%$ skim milk (caseinase test), 1\% DNA with $0.005 \%$ methyl green (dnases test), and $10 \%$ egg yolk (lecithinase test) as substrate. Besides, these strains were tested for $\beta$ hemolytic activity on nutrient agar supplemented with $7 \%$ rabbit erythrocytes. These plates were incubated for $24-48 \mathrm{~h}$ at $28^{\circ} \mathrm{C}$, and the presence of the lytic halo around the colonies was observed.

\section{Virulence-Related Genes Assay of Starved Cells}

The 6-months starved $V$. anguillarum was subjected to PCR assays to detect the virulence-related genes, including structural genes of the flagellum (flaA, flaD, flaE), the haemolysin genes (vah1,vah2, vah3, vah4, and vah5), the virulence regulator gene $($ toxR), the cell surface components genes (virA, virB, and $\operatorname{vir} C)$, zinc metalloprotease gene $(\operatorname{empA})$, trans-acting transcriptional activator ( $a n g M, a n g R)$ repeat in toxin gene $(r t x \mathrm{~A})$, iron vibriocin transport gene $(\operatorname{ton} B)$, cell division protein gene $(f t s Z)$, rod shaping protein gene $B$ subunit $(m r e B)$, and regulation of specific gene expression gene $(r p o S)$. The specific primers used are shown in Table 1. The following components were added into the mix to obtain $25 \mu \mathrm{L}$ of PCR mixture: $12.5 \mu \mathrm{L}$ of $2 \times$ Easy Taq PCR Super ${ }^{\circledR}$ Mix (TRANS), $0.5 \mu \mathrm{L}$ of each of the primers $(10 \mu \mathrm{M}), 1 \mu \mathrm{L}$ of DNA template, and $10.5 \mu \mathrm{L}$ of $\mathrm{ddH}_{2} \mathrm{O}$. The thermal cycling protocol used included initial denaturation at $94^{\circ} \mathrm{C}$ for $5 \mathrm{~min}$, followed by 30 cycles of denaturation at $94^{\circ} \mathrm{C}$ for $1 \mathrm{~min}$, annealing at $52-60^{\circ} \mathrm{C}$ for $30 \mathrm{~s}$, and extension at $72^{\circ} \mathrm{C}$ for $1 \mathrm{~min}$. A final extension step of $72^{\circ} \mathrm{C}$ for $7 \mathrm{~min}$ was also applied.

\section{Bacterial Virulence Assay}

The pathogenicity of 6-months starved and non-starved $V$. anguillarum was tested in healthy half-smooth tongue sole raised in aquaria containing $80 \mathrm{~L}$ of seawater supplemented with oxygen. The starved and non-starved $V$. anguillarum cells were streaked onto $2216 \mathrm{E}$ nutrient agar plates, and incubated at $28^{\circ} \mathrm{C}$ for $24 \mathrm{~h}$. Then purified 6 -months starved and nonstarved $V$. anguillarum was cultured at $28^{\circ} \mathrm{C}$ for $24 \mathrm{~h}$ in $2216 \mathrm{E}$ liquid medium. Twenty fish (average $8-10 \mathrm{~cm}$ in length) in each group were injected intraperitoneally with $0.1 \mathrm{~mL}$ live cells with bacteria ranging from $10^{4}$ to $10^{7} \mathrm{CFU} / \mathrm{mL}$. The control fish were inoculated with $0.1 \mathrm{~mL}$ sterile saline solution. Inoculated fish were cultured at $25^{\circ} \mathrm{C}$ and observed for 7 days. Average values were taken for calculating percentage of mortality, and the median lethal dose $\left(L D_{50}\right)$ values were calculated as described by Behreans and Karber (1953). All experiments were repeated
TABLE 1 | Sequence of primers used for detection of virulence genes.

\begin{tabular}{|c|c|c|c|}
\hline $\begin{array}{l}\text { Target } \\
\text { gene }\end{array}$ & $\begin{array}{l}\text { Product } \\
\text { size (bp) }\end{array}$ & $\begin{array}{l}\text { PCR primers } \\
\text { sequence }\left(5^{\prime}-3^{\prime}\right)\end{array}$ & References \\
\hline \multirow[t]{2}{*}{ empA } & 248 & F: CCTITAACCAAGTGGGCGTA & $\begin{array}{l}\text { Chen et al., } \\
2005\end{array}$ \\
\hline & & R: CGATITGTAAGGGCGACAAT & \\
\hline \multirow[t]{2}{*}{ vah1 } & 493 & F: TGCGCTATATTGTCGATITCAGTT & $\begin{array}{l}\text { Rodkhum } \\
\text { et al., } 2006\end{array}$ \\
\hline & & R: GCACCCGTTGTATCATCATCTAAG & \\
\hline \multirow[t]{2}{*}{ vah2 } & 876 & F: ATGAACGAAGATAACCCCCAGA & $\begin{array}{l}\text { GenBank } \\
\text { AB189395 }\end{array}$ \\
\hline & & R: TCACTCTTCTGCTATCACTGG & \\
\hline \multirow[t]{2}{*}{ vah3 } & 1128 & $\begin{array}{l}\text { F: } \\
\text { ATGACTTCTTCTAAATITCGTTATGTGCG }\end{array}$ & $\begin{array}{l}\text { GenBank } \\
\text { AB189396 }\end{array}$ \\
\hline & & R: GATAGAGCGGACTITGCTTG & \\
\hline \multirow[t]{3}{*}{ vah4 } & 603 & F: ATGAAAACCATACGCTCAGCATCT & $\begin{array}{l}\text { Rodkhum } \\
\text { et al., } 2006\end{array}$ \\
\hline & & $\mathrm{R}:$ & \\
\hline & & TCACGCTTGTIITGGTITAAATGAAATCG & \\
\hline \multirow[t]{2}{*}{ vah5 } & 1758 & F: ATGCTCACGATAAGCCCTITAAGAT & $\begin{array}{l}\text { GenBank } \\
\text { AB189398 }\end{array}$ \\
\hline & & R: TCAAGGGTTAGGCGCGTGAT & \\
\hline \multirow[t]{2}{*}{$r+x A$} & 441 & F: GCCTTCTTCGCCTAAACCT & $\begin{array}{l}\text { GenBank } \\
\text { EU155486 }\end{array}$ \\
\hline & & R: ATTCGCAGCCACTACCAG & \\
\hline \multirow[t]{2}{*}{ flaA } & 435 & F: GTGCTGATGACTTCCGTATGG & Lu, 2010 \\
\hline & & R: GCTCTGCCCGTTGTGAATC & \\
\hline \multirow[t]{2}{*}{ flaD } & 425 & F: TGACAGCACAGCGTTACCT & $\begin{array}{l}\text { McGee et al., } \\
1996\end{array}$ \\
\hline & & R: GTTATCCGCACCGATITG & \\
\hline \multirow[t]{2}{*}{ flaE } & 431 & F: CAGCCTGCTTCAGCGTAT & $\begin{array}{l}\text { McGee et al., } \\
1996\end{array}$ \\
\hline & & R: TTGCCCATTGATGTAGGT & \\
\hline \multirow[t]{2}{*}{ virC } & 344 & F: TCCTTCCTTGTGGTTAGCATTG & Lu, 2010 \\
\hline & & R: GCCTCCGCAATAATCCAGTC & \\
\hline \multirow[t]{2}{*}{$\operatorname{ton} B$} & 195 & F: GGCGTAGAAGGTाTCGTा & $\begin{array}{l}\text { GenBank } \\
\text { AY644719 }\end{array}$ \\
\hline & & R: CTCCACAGTCACGGTITG & \\
\hline \multirow[t]{2}{*}{ mreB } & 711 & F: GCGTGATTGCGGATITC & $\begin{array}{l}\text { GenBank } \\
\text { DQ907406 }\end{array}$ \\
\hline & & R: CGACTGGTATTCCCGTTC & \\
\hline \multirow[t]{2}{*}{ toxR } & 397 & F: AACACCACCAACGAGCCT & $\begin{array}{l}\text { GenBank } \\
\text { AB042547 }\end{array}$ \\
\hline & & R: GACCACCAGTCGCAATCA & \\
\hline \multirow[t]{2}{*}{ rpos } & 492 & F: CAAAGCGATGACGATG & $\begin{array}{l}\text { GenBank } \\
\text { AY695434 }\end{array}$ \\
\hline & & R: TTCTTCTGCGGTAGGTTC & \\
\hline \multirow[t]{2}{*}{$f t s Z$} & 185 & F: ATITGCGAGTGCGAATGA & $\begin{array}{l}\text { GenBank } \\
\text { DQ907334 }\end{array}$ \\
\hline & & R: CCATCTCTGCCGCTTCT & \\
\hline \multirow[t]{2}{*}{ angM } & 453 & F: TGAAGTTGAGCCTCGTAA & Lu, 2010 \\
\hline & & R: TCAGACCTGTTGATTCGT & \\
\hline \multirow[t]{2}{*}{ angR } & 957 & F: AAGAGTGAGCCAATGCGTAG & $\begin{array}{l}\text { Chen et al., } \\
1996\end{array}$ \\
\hline & & R: CTCCGAATCCATAACGATGA & \\
\hline \multirow[t]{2}{*}{ virA } & 314 & F: TCAGAGAGGATTGATAGGT & Lu, 2010 \\
\hline & & R: ACACTTATGGGATGTAACAC & \\
\hline \multirow[t]{2}{*}{ virB } & 496 & F: GTAGAACGGCAGATTGGT & Lu, 2010 \\
\hline & & R: GAGCCATAGCGATAGATTG & \\
\hline
\end{tabular}


three times. All the treatments involving animals were strictly in accordance with the guidelines of Animal Experiment Ethics Committee of Yangzhou University.

\section{RNA Extraction, Library Construction, and Illumina Sequencing}

Total RNA was extracted from 6-months starved and negative control group cells using the EasyPure RNA kit (TransGen Biotech, Beijing, China) according to the manufacturer's instructions. The integrity and size distribution of the dissolved RNA samples was checked with Agilent 2100 Bioanalyzer (Agilent technologies, USA) before storage at $-80^{\circ} \mathrm{C}$. The cDNA was reverse transcribed from these RNA samples and then quantified using several kits according to the manufacturer's instructions as previously reported. Briefly, mRNA was purified from total RNA using poly-T oligo-attached magnetic beads. The rRNA was removed using a kit that leaves behind the mRNA. All mRNA was broken into short fragments by adding a fragmentation buffer. Considering these short fragments random hexamer-primer was used to synthesize the first-strand cDNA. The second-strand cDNA was synthesized using a buffer, dATPs, dGTPs, dCTPs, dUTPs, RNase $\mathrm{H}$, and DNA polymerase I after removing dNTPs. The purified fragments were further subjected to the addition of poly (A) addition and end reparation. Afterwards, the short fragments were connected with sequencing adapters and the UNG enzyme was used to degrade the secondstrand cDNA. Then the product was purified by MiniElute PCR Purification Kit before PCR amplification. The library was sequenced on the Illumina Hiseq2500 platform at Novogene Co., Ltd. (Beijing, China).

\section{Transcriptome Analysis}

The clean reads of starved and non-starved samples were acquired from the raw data by removing the adaptors, poly$\mathrm{N}$, and low-quality reads. Next, we compared the clean reads with the reference genome and sequence using Bowtie2. Gene coverage, i.e., ratio of observed reads to the number of total nt bases, was also checked during the clean read comparison. The false discovery rate (FDR) was set at 0.0001 to determine the threshold of the $P$-value in multiple tests. Calculation of expression was applied by FPKM (Fragments Per kb per Million reads) method (Mortazavi et al., 2008). The resulting $P$-values were adjusted using the Benjamini and Hochberg's approach for controlling the false discovery rate. Genes that were differentially expressed between the starved and non-starved samples were determined by the DESeq R package, with a $q$-value $<0.05$ and absolute value of $\log 2$-fold change $>1$ set as the threshold for significance of gene differential expression. In addition, Gene Ontology (GO) analysis and Kyto Encyclopedia Genes and Genomes (KEGG) enrichment analysis of DEGs were used to annotate and classify the differentially expressed genes (Conesa et al., 2005; Kanehisa et al., 2014).

\section{Validation of Genes Using qRT-PCR}

Eight genes including vah (hemolysin), toxR (transcriptional regulator), LuxR (LuxR family transcriptional regulator), CheY (chemotaxis protein), $f l g A, f l g C, f l g D$ (flagellar protein), and
fliD (flagellar cap protein) were selected for the confirmation of RNA-seq data by Quantitative real-time PCR (qRT-PCR). The RNA samples were extracted using an EasyPure RNA kit (TransGen Biotech, Beijing, China), according to the manufacturer's instructions. The cDNAs were then synthesized using a TransScript One-Step gDNA Removal and cDNA Synthesis Supermix (TransGen Biotech, Beijing, China), as recommended by the manufacturer. 16S rRNA was used as the internal control. The primers used for qRT-PCR are shown in Table 2. Real-time PCR was performed using the Roche LightCycler ${ }^{\circledR} 96$ System with a TransStart Top Green qPCR SuperMix following the instructions of the manufacturer. The relative gene expressions were determined using $2^{-\Delta \Delta C t}$ method. The expression of the detected genes was analyzed by One-Way ANOVA using SPSS 16.0. All quantitative data were expressed as means \pm SD.

\section{RESULTS}

\section{Phenotype Changes Under Starvation Stress}

The scanning electron micrograph revealed that the non-starved $V$. anguillarum were mainly short rods, and changed to spheres after the 6-months starvation. After 6-months starvation, the average cell length of the initial $V$. anguillarum had significantly decreased from $2.0 \pm 0.2 \mu \mathrm{m}$ to $1.0 \pm 0.2 \mu \mathrm{m}$ (Figure 1). Additionally, the starved cells showed a rippled surface, much rougher than that of the non-starved cells. Furthermore, the motility of $V$. anguillarum was determined by measuring the diameter of the halo on the agar plate. The results in Figure 2 showed that the motility of $V$. anguillarum decreased after starvation. In addition, the phenotypic determination of putative virulence factors showed that the 6-months starved cells could

TABLE 2 | Primers used for the detection of DEGs by qRT-PCR.

\begin{tabular}{|c|c|}
\hline Target gene & PCR primers sequence $\left(5^{\prime}-3^{\prime}\right)$ \\
\hline \multirow[t]{2}{*}{ vah } & F: ATTGTCTGGCGGTGAAAG \\
\hline & R: GGTGCTGCACATCTAACG \\
\hline \multirow[t]{2}{*}{ toxR } & F: ATCTAACCGATGACTACTTGA \\
\hline & R: TCGTTGATGACCCTGACT \\
\hline \multirow[t]{2}{*}{ CheY } & F: ACAGCCACTTGAGTCTACGA \\
\hline & R: TTATTGCGCCACTTTCCA \\
\hline \multirow[t]{2}{*}{ LuxR } & F: ATGTGGATTTGCTGCTGT \\
\hline & F: AGGCGATTTGTTGTTGA \\
\hline \multirow[t]{2}{*}{ flaA } & F: TGCGGCAGGCTTACAAAT \\
\hline & R: CCTTGTCCTITCCTTGCTCTGCAAG \\
\hline \multirow[t]{2}{*}{ flac } & F:CGGCAAATGGACAAGATA \\
\hline & R:CACCCAGTTGAGCACGAT \\
\hline \multirow[t]{2}{*}{ flaD } & F: GACAGCACAGCGTTACCT \\
\hline & R: TCATTCATCGCACCCTCA \\
\hline \multirow[t]{2}{*}{ fliD } & F: GCTCAAAGAGTCGCTGGAT \\
\hline & R: TGATTACCGAAGCACGAA \\
\hline
\end{tabular}



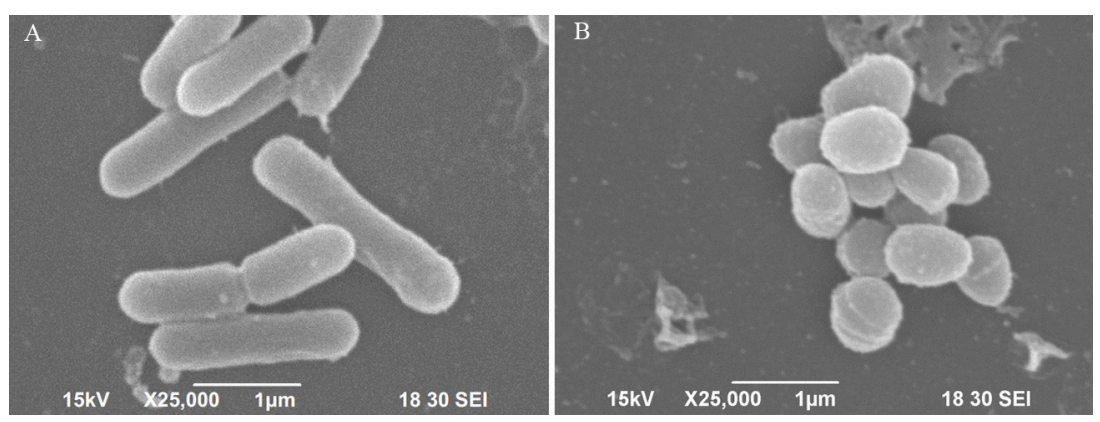

FIGURE 1 | Morphological changes of $V$. anguillarum cells after starvation revealed by scanning electronic microscopy. (A) Initial cells, (B) 6-months starved cells.

still produce $\beta$-hemolysis on rabbit blood agar, caseinase, dnase, and gelatinase.

\section{Survival of the Starved $V$. anguillarum}

The survival rate of $V$. anguillarum $\mathrm{BH} 1$ under starvation at $28^{\circ} \mathrm{C}$ was determined over a 6 -months period. The cell enumeration of $V$. anguillarum $\mathrm{BH} 1$ is shown in Figure 3. Overall, $V$. anguillarum BH1 was still culturable after 6 months of starvation. The cell counts were on the decline during the 6months starvation period with $\log 10 \mathrm{CFU} / \mathrm{mL}$ changing from $9.7224 \pm 0.2254$ to $3.6877 \pm 0.1966$.

\section{Virulence Related Genes of Starved Cells}

The PCR profiles of the amplified virulence-related genes from the starved cells are presented in Figure 4. The results showed that empA, vah1, vah2, vah3, vah4, vah5, rtxA, flaA, flaD, flaE, vir $\mathrm{C}, \operatorname{ton} \mathrm{B}, m r e \mathrm{~B}$, tox $\mathrm{R}, r p o \mathrm{~S}$, and $f t s \mathrm{Z}$ genes were detected in the starved cells. However, ang $\mathrm{M}$, angR, virA, and $v i r \mathrm{~B}$ genes were not detected using the given primers in this study.

\section{Pathogenicity of Starved V. anguillarum}

The non-starved and 6-months starved $V$. anguillarum were used to infect a half-smooth tongue sole. The results showed that the $V$. anguillarum starved for 6 months were able to infect a halfsmooth tongue sole by intraperitoneal injection. As shown in Table 3, the starved cells presented an overall decline of virulence compared to that of the non-starved cells. The $L D_{50}$ value of non-starved and 6-months starved was $1.747 \times 10^{6} \mathrm{CFU} / \mathrm{mL}$ and $7.357 \times 10^{6} \mathrm{CFU} / \mathrm{mL}$ for half-smooth tongue sole, respectively.

\section{Sequencing Quality Assessment and Gene Expression Annotation}

To identify the molecular mechanisms involved in response to starvation, cDNA samples of $V$. anguillarum strain BH1 with and without starvation treatment were sequenced using Illumina $\mathrm{HiSeq}^{\mathrm{TM}} 2500$ system. After removing adaptors, poly$\mathrm{N}$, and low-quality reads, a total of $16,430,586$ clean reads for control group cells and 14,126,118 reads for starved cells were obtained. Proportions of clean reads mapped back to genome and genes can provide an overall assessment of the sequencing. After the alignment of the sequence reads with the reference genome sequence of $V$. anguillarium, a total of 93.24 and $93.81 \%$

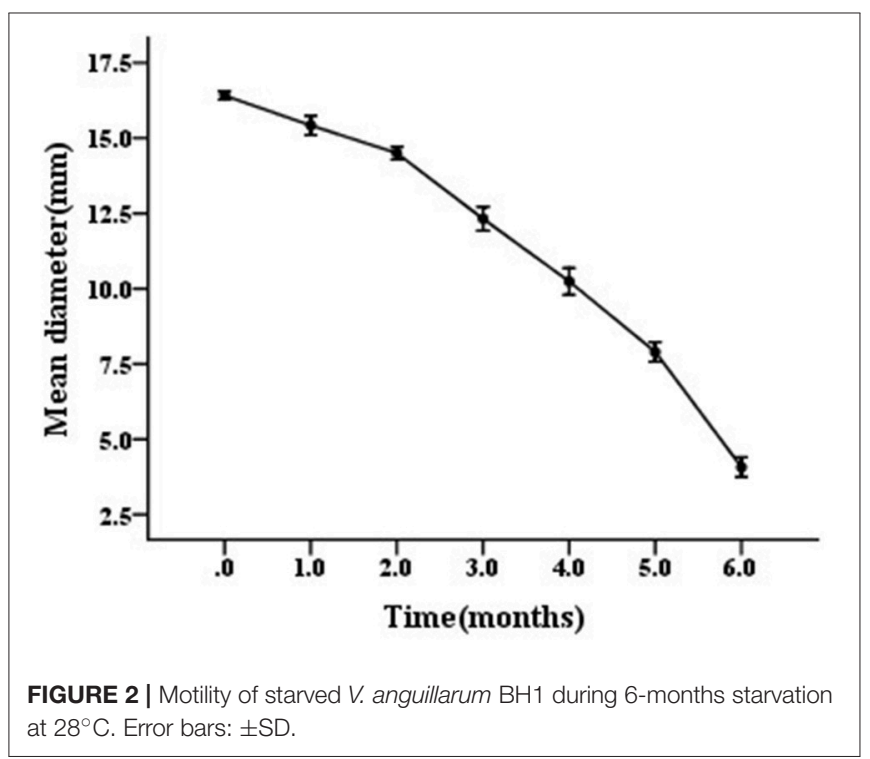

clean reads could be mapped in control and starved groups, respectively (Table 4). Only those reads entirely aligning within exonic regions matched (reads from exon-exon junction regions did not match). In addition, the sequencing results indicated that $V$. anguillarum strain BH1 expressed 3,089 and 3,072 annotated genes before and after starvation stress (Table 5).

\section{GO Analysis of Differently Expressed Genes}

Compared to the untreated group, a total of 523 differently expressed genes (DEGs) were identified in the 6-months starved group, including 251 up-regulated genes and 272 down-regulated genes. This means that $17.0 \%$ of the total number of gene expression levels had significantly changed after starvation for 6 months. GO analysis aims to annotate genes and gene products, and assimilate and disseminate annotation data via enrichment analysis. The differently expressed genes of $V$. anguillarum after nutritional stress were enriched by GO enrichment analysis and classified into three major categories: biological process, cellular component, and molecular function (Figure 5). In the biological process category, the top three categories were gene expression, 
cellular macromolecule biosynthetic process, and macromolecule biosynthetic process. In the cellular component category, the most abundant categories of the differential expression genes were cellular component, cell, and cell part. In the molecular function category, two of the most enriched terms were structural molecule activity and structural constituent of ribosome.

\section{KEGG Enrichment Analysis of Differently Expressed Genes}

Genes that interact with each other play an important role in generating a response to environmental stress. To perform functional classification and pathway assignment of genes after starvation stress in $V$. anguillarum, all DEGs were analyzed based on the KEGG database. KEGG enrichment analysis of differentially expressed genes revealed that the DEGs clustered to 122 biochemical metabolism and signal pathways. The most

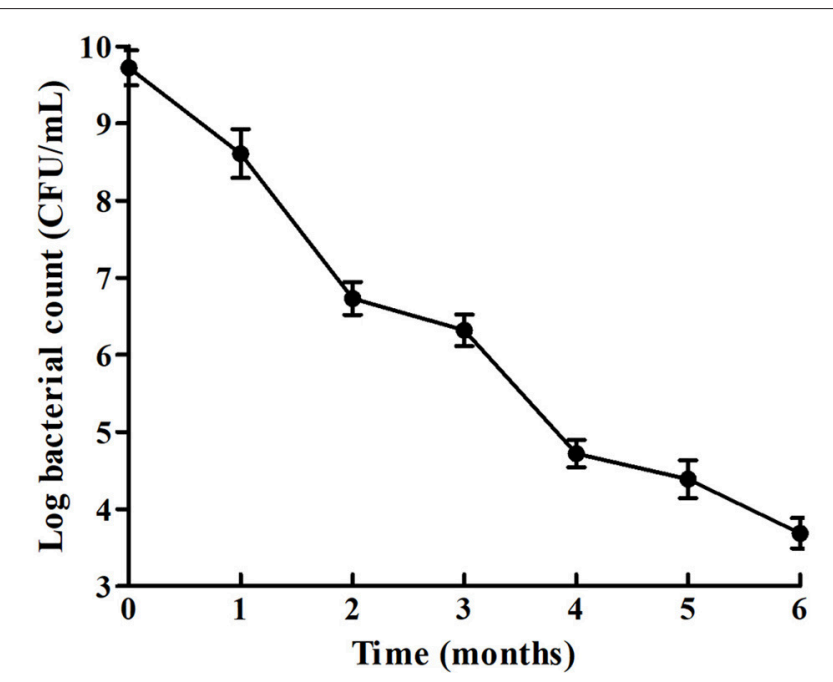

FIGURE 3 | Survival curves of $V$. anguillarum BH1 under starvation stress. Error bars: \pm SD. abundant pathways were fructose and mannose metabolism, citrate cycle (TCA cycle), and pyruvate metabolism. However, all $p$-values of the three pathways were $>0.05$, indicating that these metabolic pathways were not significantly influenced during starvation. Figure 6 shows that these transcripts, mainly belonging to ribosome, flagellar assembly, and two-component system, were significantly $(p<0.05)$ induced after starvation.

\section{Verification of the DEGs by qRT-PCR}

To further validate the Illumina sequencing data and the differential expression level of the DEGs in the sequencing results, eight differentially expressed genes in the transcriptome data were purposefully selected for relative quantitative real-time PCR. Among these selected genes, four genes (Vah, toxR, LuxR, and $C h e Y)$ were up-regulated and the other four genes $(f g A$, $f l g C, f l g D$, and $f l i D)$ were down-regulated. The qRT-PCR results exhibited a similar expression tendency at transcriptome analysis, which confirmed the reliability of transcriptome sequencing results (Figure 7).

\section{DISCUSSION}

Vibrio are widespread in coastal and estuarine environments. Some species, e.g., V. anguillarum and V. parahaemolyticus, are serious pathogens of aquatic vertebrates or invertebrates, and their serotypes may be diverse (Austin, 2010; Li et al., 2010). At present, $23 \mathrm{O}$ serotypes $(\mathrm{O} 1-\mathrm{O} 23)$ within $V$. anguillarum are distinguished, each displaying a different pathogenicity and host specificity. Of these, only serotypes $\mathrm{O} 1$ and $\mathrm{O} 2$, and to a lesser extent serotype $\mathrm{O} 3$, are associated with vibriosis in fish (Frans et al., 2011); and at least $13 \mathrm{O}$ serotypes have been identified in $V$. parahaemolyticus (Broberg et al., 2011; Xu et al., 2014). However, the responses of the different serotypes of bacteria to survival, pathogenicity, and gene expression under environment stress are not well-understood. Romalde et al. (1994) reported that serotypes of Yersinia ruckeri reflected similar survival dynamics under starvation stress. Eguchi et al. (2003) reported that $V$. anguillarum serotype $\mathrm{O} 1$ can survive in freshwater under starved

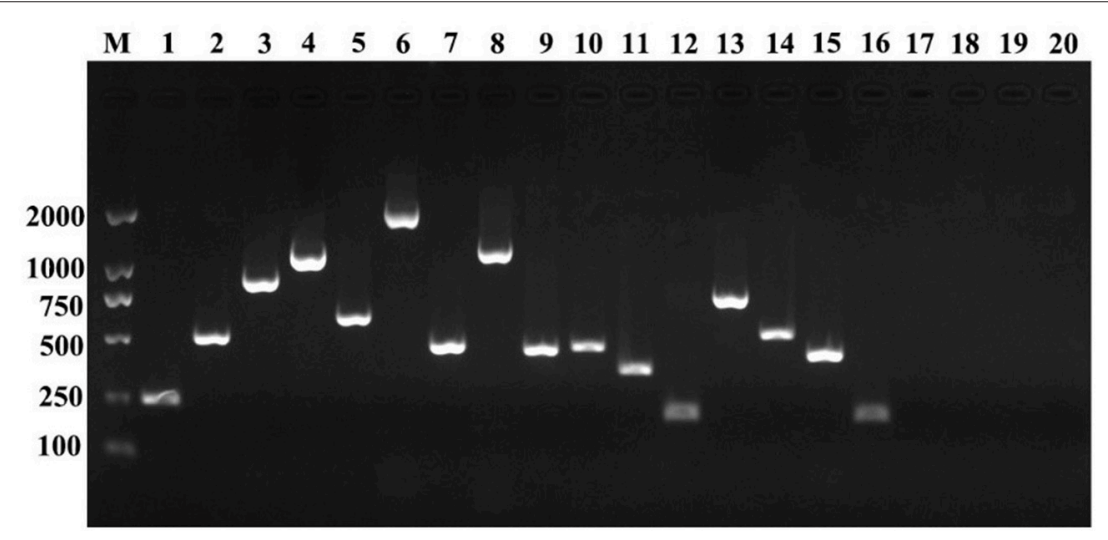

FIGURE 4 | Detection of virulence-related genes of the initial V. anguillarum cells. M, DL 2000; lane 1, empA; lane 2, vah1; lane 3, vah2; lane 4, vah3; lane 5, vah4; lane 6, vah5; lane 7, rtxA; lane8, flaA; lane 9, flaD; lane 10, flaE; lane 11, virC; lane 12, tonB; lane 13, mreB; lane 14, toxR; lane 15, rpoS; lane 16, ftsZ; lane 17, angM; lane 18, angR; lane 19, virA; lane 20, virB. 
TABLE 3 | Pathogenicity of non-starved and 6-months starved V. anguillarum to half-smooth tongue sole.

\begin{tabular}{|c|c|c|c|c|c|c|c|c|c|c|c|}
\hline \multirow[t]{2}{*}{ Bacteria } & \multirow[t]{2}{*}{ Fish amount } & \multirow[t]{2}{*}{ Bacterial concentration (CFU/mL) } & \multicolumn{8}{|c|}{ Number of dead fish during infection (day) } & \multirow[t]{2}{*}{ Mortality (\%) } \\
\hline & & & 1 & 2 & 3 & 4 & 5 & 6 & 7 & Total & \\
\hline \multirow[t]{4}{*}{ Non-starved cells } & 20 & $3.6 \times 10^{7}$ & 0 & 9 & 8 & 3 & 0 & 0 & 0 & 20 & 100.0 \\
\hline & 20 & $3.6 \times 10^{6}$ & 0 & 4 & 6 & 0 & 1 & 0 & 0 & 11 & 55.0 \\
\hline & 20 & $3.6 \times 10^{5}$ & 0 & 2 & 3 & 0 & 0 & 0 & 0 & 5 & 25.0 \\
\hline & 20 & $3.6 \times 10^{4}$ & 0 & 0 & 0 & 0 & 0 & 0 & 0 & 0 & 0.0 \\
\hline \multirow[t]{4}{*}{ Starved cells } & 20 & $3.2 \times 10^{7}$ & 0 & 3 & 7 & 4 & 1 & 0 & 0 & 15 & 75.0 \\
\hline & 20 & $3.2 \times 10^{6}$ & 0 & 0 & 3 & 3 & 0 & 0 & 0 & 6 & 30.0 \\
\hline & 20 & $3.2 \times 10^{5}$ & 0 & 0 & 0 & 3 & 0 & 0 & 0 & 3 & 15.0 \\
\hline & 20 & $3.2 \times 10^{4}$ & 0 & 0 & 0 & 0 & 0 & 0 & 0 & 0 & 0.0 \\
\hline Control & 20 & 0 & 0 & 0 & 0 & 0 & 0 & 0 & 0 & 0 & 0.0 \\
\hline
\end{tabular}

Data are presented as average value of three repeats at each concentration.

TABLE 4 | Summary of the reads mapping to the reference transcriptome of the control group and the starvation stress group.

\begin{tabular}{lcc}
\hline Item & $\begin{array}{c}\text { Control group } \\
\text { (Mapping to } \\
\text { Genome) }\end{array}$ & $\begin{array}{c}\text { Starvation stress } \\
\text { group (Mapping to } \\
\text { Genome) }\end{array}$ \\
\hline Total reads & $16,430,586$ & $14,126,118$ \\
Total mapped & $15,320,669(93.24 \%)$ & $113,251,878(93.81 \%)$ \\
Multiple mapped & $794,433(4.84 \%)$ & $904,200(6.4 \%)$ \\
Uniquely mapped & $14,526,236(88.41 \%)$ & $12,347,678(87.41 \%)$ \\
\hline
\end{tabular}

TABLE 5 | The gene coverage of RNA-seq of $V$. anguillarum strain $\mathrm{BH} 1$ before and after starvation treatment.

\begin{tabular}{lcc}
\hline FPKM interval & Control group & Starvation stress group \\
\hline $0-1$ & $616(16.63 \%)$ & $633(17.09 \%)$ \\
$1-3$ & $36(0.97 \%)$ & $40(1.08 \%)$ \\
$3-15$ & $217(5.86 \%)$ & $224(6.05 \%)$ \\
$15-60$ & $659(17.79 \%)$ & $662(17.87 \%)$ \\
$>60$ & $2,177(58.76 \%)$ & $2,146(57.92 \%)$ \\
\hline Total number of expressed genes & $3,089(83.87 \%)$ & $3,072(82.91 \%)$ \\
\hline
\end{tabular}

FPKM interval >1: gene expression.

and low osmotic environment and is potentially the causative agent for the vibriosis of ayu. Miyamoto and Eguchi (1997) reported that a high cell density and small amounts of divalent cations in freshwater made $V$. anguillarum serotype $\mathrm{O} 1$ more resistant to low osmotic stress. However, the survival strategies of $V$. anguillarum to withstand different kinds of environmental stress in the aquatic environment are not well-understood. In this study, $V$. anguillarum strain $\mathrm{BH} 1$ was originally isolated from diseased half-smooth tongue sole, which caused mass mortalities, and we focused on the changes of the morphology, survival, virulent characteristics, and transcriptomic analyses of $V$. anguillarum $\mathrm{BH} 1$ induced by starvation.

It is well-known that lack of nutrients is the most common environmental stress which microorganisms will frequently confront in natural ecosystems (Kjelleberg et al., 1983; Wai et al., 1999; Desnues et al., 2003; Vatsos et al., 2003; GonzálezEscalona et al., 2006; Su et al., 2015). In this study, the survival of $V$. anguillarum starved at $28^{\circ} \mathrm{C}$ over a 6 -months period has been investigated. The cell viability revealed that $V$. anguillarum was still culturable after 6 months of starvation. Our results are consistent with previous reports that Vibrio spp. can survive for long periods, even several years, during starvation as culturable bacteria (Amel et al., 2008). In this study, the number of culturable bacteria declined gradually with time. For instance, some species would adopt an adaptive strategy, entering the so-called viable but non-culturable (VBNC) state, under stress conditions and wait for recovery until optimal conditions are restored (Igbinosa and Okoh, 2008; Su et al., 2013). According to Amel et al. (2008), V. fluvialis cells in the VBNC state could be metabolically reactivated, and their study showed that resuscitation of VBNC population was achieved after $48 \mathrm{~h}$. The focus of our study was to understand the genetic modulations in $V$. anguillarum during starvation, including stress-induced morphological changes. Vibrio anguillarum cells showed a remarkable reduction in size, turning from rods to sphere, and the cell surface appeared rippled and much thicker after starvation. The morphological changes could be due to the nutrient deficiency. Besides, the starved bacteria showed rippled cell surface, which is likely to affect the attachment and colonization capabilities of this fish pathogen, leading to the variation in virulence potential. The changes observed in cell morphology during bacterial starvation were most likely an adaptive process to minimize the requirements for cell maintenance, and avail better protection against predation and other environmental stresses (Chaiyanan et al., 2007). The appearance of irregular rod-shaped cells has been demonstrated for VBNC V. cholerae and V. parahaemolyticus (Jiang and Chai, 1996; Chaiyanan et al., 2007; Abdallah et al., 2010).

Environmental stresses may stimulate the expression of genes encoding products which protect the cells from the stresses, participate in the repair of cellular damage and can cause diseases in the organism. In our study, motility of $V$. anguillarum was weaken after starvation. Meanwhile, the infectivity of the $V$. anguillarum had also decreased after starvation, indicating that starvation can attenuate the intensity of bacterial virulence 


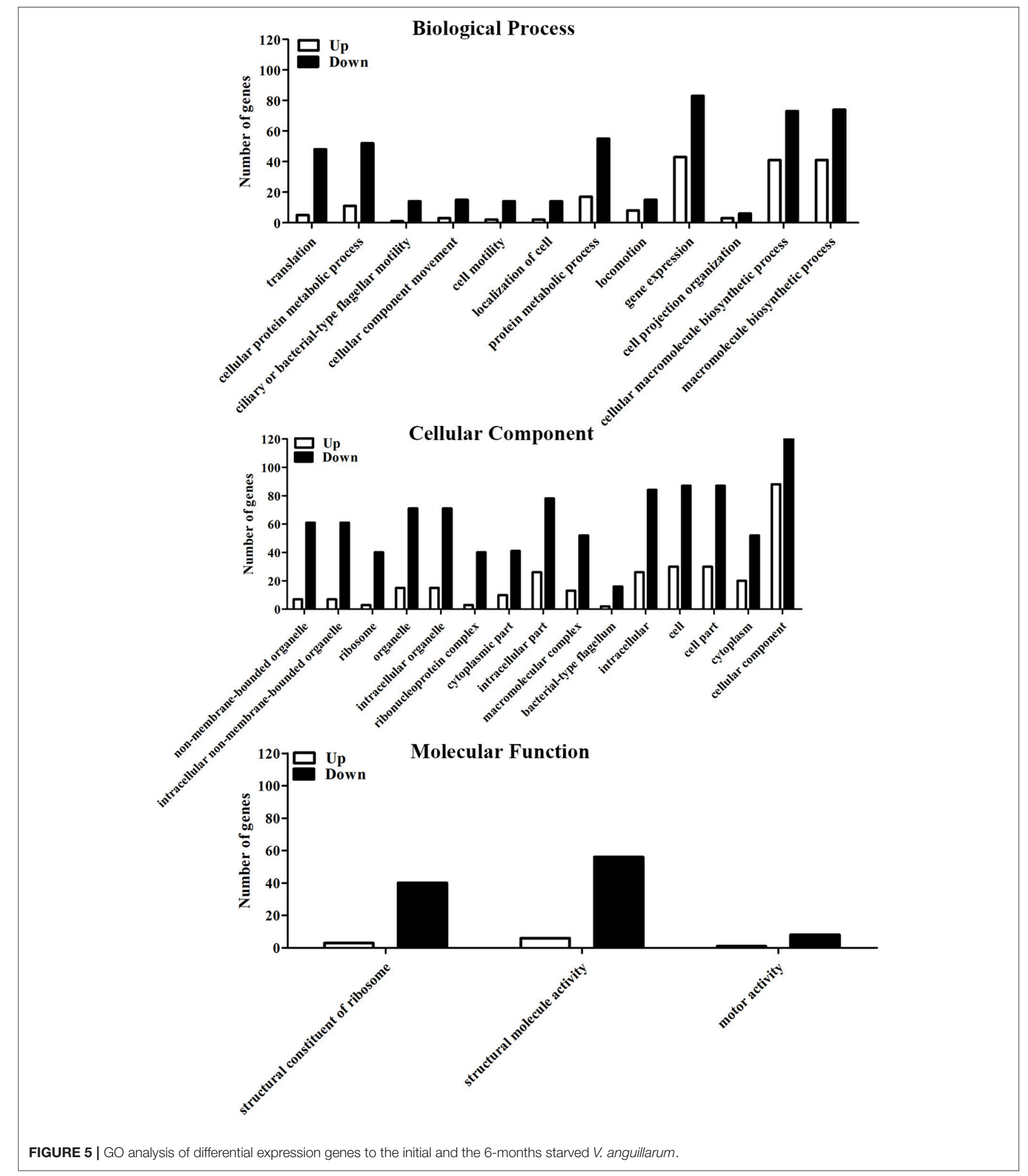

to the examined fish (half-smooth tongue sole) but does not completely diminish its pathogenic potential. Moreover, the detection of virulence factors and virulence-related genes in starved $V$. anguillarum $\mathrm{BH} 1$ showed that the starved strain still produced $\beta$-hemolysis on rabbit blood agar, caseinase, dnase, and gelatinase, and possessed empA, vah1, vah2, vah3, 


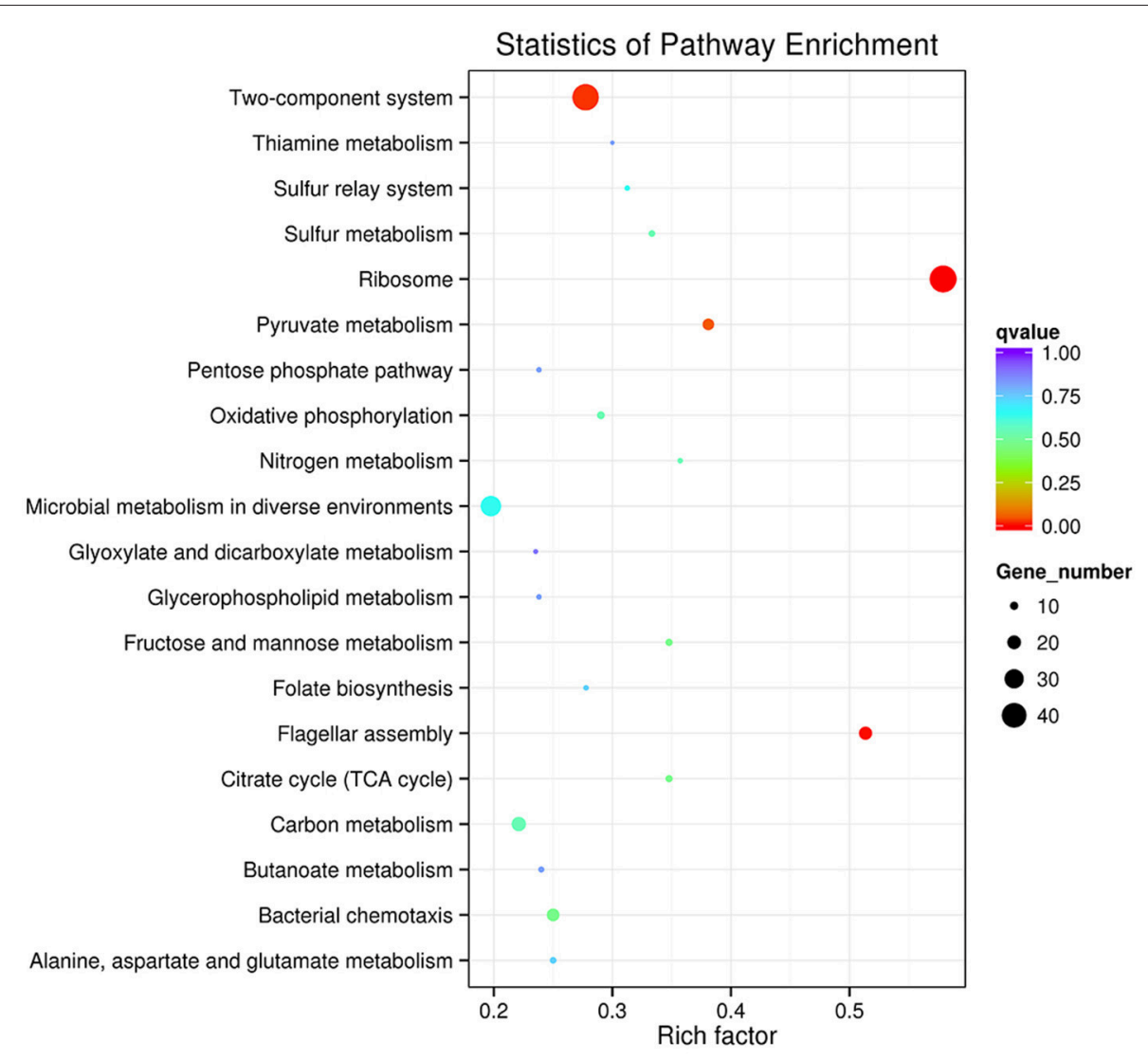

FIGURE 6 | The Top20 pathways with the most significant $p$-value. The $x$-axis indicates percentages of DEGs belonging to the corresponding pathway. The left $y$-axis represents the top 20 pathways. The sizes of the bubbles represent the number of DEGs in the corresponding pathway, and the colors of the bubbles represent the enrichment $p$-value of the corresponding pathway. KEGG terms with $P$-value $<0.05$ were considered significantly enriched by differential expressed genes.

vah4, vah5, rtxA, flaA, flaD, flaE, vir $\mathrm{C}$, ton $\mathrm{B}, m r e \mathrm{~B}$, toxk, rpoS, and ftsZ virulence-related genes. The expression of these virulence genes in $V$. anguillarum may be affected by starvation. Crisafi et al. (2014) reported that environmental stress affects the expression of virulence genes in $V$. anguillarum, e.g., transcription levels of empA, angR, and fat $A$ increased under conditions of $15^{\circ} \mathrm{C}$ and iron depletion, which have implications on the competitiveness, stress tolerance, and the ability of $V$. anguillarum to cause infection. Similarly, Saint-Ruf and Matic (2006) reported that under nutrient limitation, the high intracellular concentration of RpoS diminished nutritional competence and increased stress resistance. Knowing the expression of genes of bacteria responding to environmental stimuli is important for understanding the factors determining pathogenicity and infection, and molecular adaptations that follow a specific stress (Boor, 2006).

Bacterial pathogens are frequently exposed to a variety of stresses in their natural environment and in their host systems, which may lead to increased virulence, adaptability, and resistance (Awan et al., 2018). Previous studies mainly focused on phenotype changes and survival of $V$. anguillarum under environmental stresses (Eguchi et al., 2000, 2003; FujiwaraNagata and Eguchi, 2004; Larsen et al., 2004; Kim et al., 2012; Crisafi et al., 2014). However, the specific events and

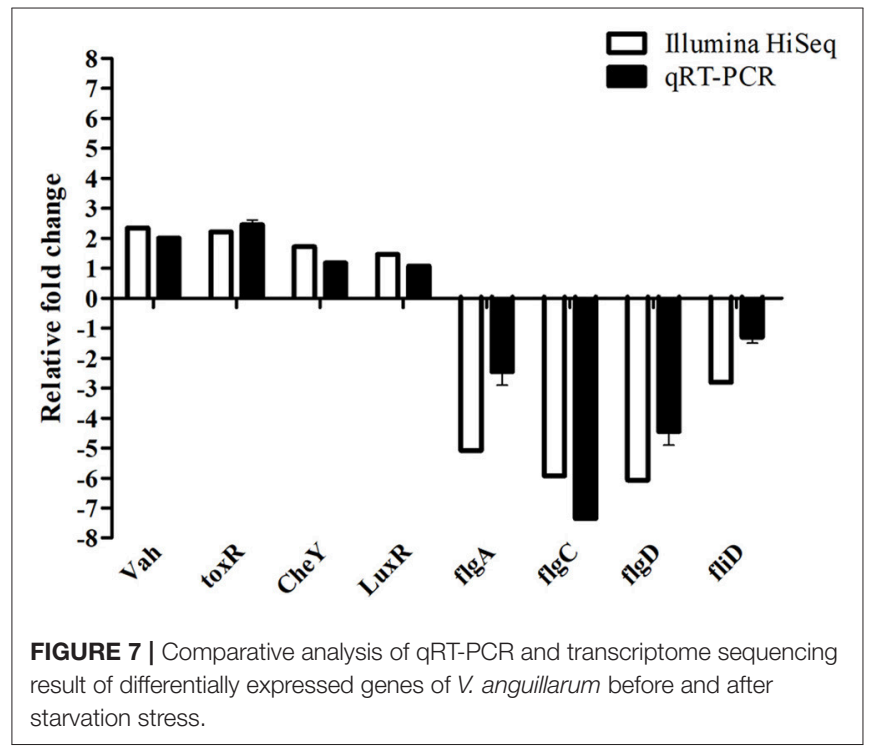

pathways at the transcriptomic level of $V$. anguillarum under environmental stress, especially in relation to survival and pathogenicity, has never been studied. To understand the survival 
ability of V. anguillarum further, performed the transcriptomic analysis of $V$. anguillarum under environmental stresses. The full transcriptome of $V$. anguillarum during starvation stress, using high-throughput sequencing, may enhance the understanding of the survival, virulence, and metabolism-related factors in environmental suitability of $V$. anguillarum.

In this study, transcriptome sequence analysis was performed to assess the variation of virulence-related and metabolismrelated factors in $V$. anguillarum and its survival abilities under starvation stresses. According to this study, 251 up-regulated genes and 272 down-regulated genes were identified after exposure to starvation stress by using the RNA-Seq technology, which very likely played an important role in generating a response to starvation stress. There were $30 \mathrm{GO}$ categories related to the starvation stress response of $V$. anguillarum and the key biological processes associated with starvation stress response may be a metabolic process, cell and catalytic activity, binding and transporter activity process. KEGG pathway analysis in this study has provided important information to explain the relationship between the gene function and regulation mechanism during the long-term survival of $V$. anguillarum. In addition to the gene enrichment pathways, there are many other significant pathways, such as ABC transporters, flagellum assembly, fatty acid degradation, fatty acid metabolism, alanine, aspartate and glutamate metabolism, which were also closely related to starvation stress (Higgins, 2001; Svensson et al., 2014). In-depth analysis of sequencing results displayed that the expressions of the nutrients that transport related genes were down-regulated, including oligopeptide, simple sugars, and phospholipids, after 6 months of starvation. However, the nutrient transfer related genes, such as monosaccharide transporters gene and phospholipid transfer protein gene were significantly up-regulated and likely to promote an active metabolism pathway in $V$. anguillarum under nutritional stress. On one side, the analysis of fatty acid metabolism pathway showed that the expression level of fatty acid synthesis-related genes were significantly down-regulated. On the other side, the expression level of fatty acid degradation-related genes were significantly increased. The functional impacts of the genes which were up-regulated or down-regulated under the starvation need to be elucidated in the future.

In our study, long-term starved cells of $V$. anguillarum, which showed reduction in size and changed from spherical to rod shape, were still culturable and pathogenic. The transcriptome sequence analysis proposed that $V$. anguillarum could survive under starvation stress by up-regulating or down-regulating a series of genes predominantly related to nutrient transfer and metabolism. The identified key genes could be important highvalue drug targets, which provide new ways to effectively control infection of $V$. anguillarum clinically.

\section{AUTHOR CONTRIBUTIONS}

XG analyzed the data and wrote the manuscript. XG, DP, NC, and XL conducted $V$. anguillarum under starvation stress assay, ultrastructural analysis, viability measure, swimming motility assay, determination of extracellular enzymes and hemolysin of starved cells, virulence gene assay of starved cells, pathogenicity of starved cells assay. XDL and HY conducted the transcriptomic analyses of the pathogenic $V$. anguillarum under starvation stress. WW and $\mathrm{XZ}$ designed the research and revised the manuscript. All authors read and gave final approval of the manuscript.

\section{ACKNOWLEDGMENTS}

This work was supported by the Science Research Foundation of the Education Ministry for Returned Chinese Scholars, the Major Natural Science Research Program of Jiangsu Higher Education Institutions (14KJA240001), the fishery science and technology innovation projects of Jiangsu Province (Y2016-33, D2017-3), the Jiangsu Fisheries Research System-02 (JFRS-02), and the Jiangsu Agricultural Science and Technology Innovation Fund (CX(18)2012).

\section{REFERENCES}

Abdallah, F. B., Ellafi, A., Lagha, R., Bakhrouf, A., Namane, A., Rousselle, J. C., et al. (2010). Identification of outer membrane proteins of Vibrio parahaemolyticus and Vibrio alginolyticus altered in response to $\gamma$-irradiation or long-term starvation. Res. Microbiol. 161, 869-875. doi: 10.1016/j.resmic.2010. 10.009

Álvarez, C. A., Acosta, F., Montero, D., Guzmán, F., Torres, E., Vega, B., et al. (2016). Synthetic hepcidin from fish: uptake and protection against Vibrio anguillarum in sea bass (Dicentrarchus labrax). Fish Shellfish Immunol. 55, 662-670. doi: 10.1016/j.fsi.2016.06.035

Amel, B. K., Amine, B., and Amina, B. (2008). Survival of Vibrio fluvialis in seawater under starvation conditions. Microbiol. Res. 163, 323-328. doi: 10.1016/j.micres.2006.06.006

Arias, C. R., Stacey, L. F., Cai, W., and Oscar, O. F. (2012). Adaptive response to starvation in the fish pathogen Flavobacterium columnare: cell viability and ultrastructural changes. BMC Microbiol. 12:266. doi: 10.1186/1471-2180-12-266

Austin, B. (2010). Vibrios as causal agents of zoonoses. Vet. Microbiol. 140, 310-317. doi: 10.1016/j.vetmic.2009.03.015

Awan, F., Dong, Y., Wang, N., Liu, J., Ma, K., and Liu, Y. (2018). The fight for invincibility: environmental stress response mechanisms and Aeromonas hydrophila. Microb. Pathogenesis 116, 135-145. doi: 10.1016/j.micpath.2018.01.023

Behreans, A. L., and Karber, L., (1953). Determination of $L D_{50}$. Screening in Pharmacology. New York, NY: Academic Press. 60.

Boor, K. J. (2006). Bacterial stress responses: what doesn't kill them can make them stronger. PLoS Biol. 4:23. doi: 10.1371/journal.pbio.0040023

Broberg, C. A., Calder, T. J., and Orth, K. (2011). Vibrio parahaemolyticus cell biology and pathogenicity determinants. Microbes Infect. 13, 992-1001. doi: 10.1016/j.micinf.2011.06.013

Chaiyanan, S., Chaiyanan, S., Grim, C., Maugel, T., Huq, A., and Colwell, R. R. (2007). Ultrastructure of coccoid viable but non-culturable Vibrio cholerae. Environ. Microbiol. 9, 393-402. doi: 10.1111/j.1462-2920.2006. 01150.x

Chen, J. X., Li, C. F., Yan, X. H., Li, Y., Chi, Z., and Xue, X. (2005). Studies on biological characteristics of five pathogenic Vibrio anguillarum strains isolated from diseased turbot (Scophthalmus maximus) in Shandong province of China. High technology communication. 15, 92-96. doi: 10.3321/j.issn:1002-0470.2005.06.021 
Chen, Q., Wertheimer, A. M., Tolmasky, M. E., and Crosa, J. H. (1996). The AngR protein and the siderophore anguibactin positively regulate the expression of iron-transport genes in Vibrio anguillarum. Mol. Microbiol. 22, 127-134. doi: 10.1111/j.1365-2958.1996.tb02662.x

Chen, S. Y., Jane, W. N., Chen, Y. S., and Wong, H. C. (2009). Morphological changes of Vibrio parahaemolyticus under cold and starvation stresses. Int. J. Food Microbiol. 129, 157-165. doi: 10.1016/j.ijfoodmicro.2008.11.009

Conesa, A., Götz, S., García-Gómez, J. M., Terol, J., Talón, M., and Robles, M. (2005). Blast2GO: a universal tool for annotation, visualization and analysis in functional genomics. Bioinformatics 21, 3674-3676. doi: 10.1093/bioinformatics/bti610

Crisafi, F., Denaro, R., Genovese, M., Yakimov, M., and Genovese, L. (2014). Application of relative real-time PCR to detect differential expression of virulence genes in Vibrio anguillarum under standard and stressed growth conditions. J. Fish Dis. 37, 629-640. doi: 10.1111/jfd.12158

Desnues, B., Cuny, C., Grégori, G., Dukan, S., Aguilaniu, H., and Nyström, T. (2003). Differential oxidative damage and expression of stress defence regulons in culturable and non-culturable Escherichia coli cells. EMBO Rep. 4, 400-404. doi: 10.1038/sj.embor.embor799

Eguchi, M., Fujiwara, E., and Miyamoto, N. (2000). Survival of Vibrio anguillarum in freshwater environments: adaptation or debilitation. J. Infect. Chemother. 6, 126-129. doi: 10.1007/PL00012152

Eguchi, M., Fujiwara-Nagata, E., and Miyamoto, N. (2003). Physiological state of Vibrio anguillarum, a fish pathogen, under starved and low-osmotic environments. Microbes Environ. 18, 160-166. doi: 10.1264/jsme2.18.160

Frans, I., Michiels, C. W., Bossier, P., Willems, K. A., Lievens, B., and Rediers, H. (2011). Vibrio anguillarum as a fish pathogen: virulence factors, diagnosis and prevention. J. Fish Dis. 34, 643-661. doi: 10.1111/j.1365-2761.2011. 01279.x

Fujiwara-Nagata, E., and Eguchi, M. (2004). Significance of $\mathrm{na}^{+}$in the fish pathogen Vibrio anguillarum under energy depleted condition. FEMS Microbiol. Lett. 234, 163-167. doi: 10.1111/j.1574-6968.2004. tb09528.x

González-Escalona, N., Fey, A., Höfle, M. G., Espejo, R. T., and Guzmán, C. A. (2006). Quantitative reverse transcription polymerase chain reaction analysis of Vibrio cholerae cells entering the viable but non-culturable state and starvation in response to cold shock. Environ. Microbiol. 8, 658-666. doi: 10.1111/j.1462-2920.2005.00943.x

Higgins, C. F. (2001). Abc transporters: physiology, structure and mechanisman overview. Res. Microbiol. 152, 205-210. doi: 10.1016/S0923-2508(01) 01193-7

Higuera, G., Bastías, R., Tsertsvadze, G., Romero, J., and Espejo, R. T. (2013). Recently discovered Vibrio anguillarum phages can protect against experimentally induced vibriosis in atlantic salmon, salmo salar. Aquaculture 392, 128-133. doi: 10.1016/j.aquaculture.2013.02.013

Igbinosa, E. O., and Okoh, A. I. (2008). Emerging Vibrio species: an unending threat to public health in developing countries. Res. Microbiol. 159, 495. doi: 10.1016/j.resmic.2008.07.001

Jiang, X., and Chai, T. J. (1996). Survival of Vibrio parahaemolyticus at low temperatures under starvation conditions and subsequent resuscitation of viable, nonculturable cells. Appl. Environ. Microb. 62:1300.

Kanehisa, M., Goto, S., Sato, Y., Kawashima, M., Furumichi, M., and Mao, T. (2014). Data, information, knowledge and principle: back to metabolism in KEGG. Nucleic Acids Res. 42, 199-205. doi: 10.1093/nar/gkt1076

Kim, E. Y., Kim, Y. R., Kim, D. G., and Kong, I. S. (2012). A susceptible protein by proteomic analysis from Vibrio anguillarum under various environmental conditions. Bioproc. Biosyst. Eng. 35, 273-282. doi: 10.1007/s00449-0110636-6

Kjelleberg, S., Humphrey, B. A., and Marshall, K. C. (1983). Initial phases of starvation and activity of bacteria at surfaces. Appl. Environ. Microb. 46, 978-984.

Larsen, M. H., Blackburn, N., Larsen, J. L., and Olsen, J. E. (2004). Influences of temperature, salinity and starvation on the motility and chemotactic response of Vibrio anguillarum. Microbiology 150, 1283-1290. doi: 10.1099/mic.0.26379-0

Li, N., Yang, Z., Bai, J., Fu, X., Liu, L., Shi, C., et al. (2010). A shared antigen among Vibrio species: outer membrane protein-OmpK as a versatile vibriosis vaccine candidate in Orange-spotted grouper (Epinephelus coioides). Fish Shellfish Immunol. 28, 952-956. doi: 10.1016/j.fsi.2010.02.010

Liu, X., Jiao, C., Ma, Y., Wang, Q., and Zhang, Y. (2018). A live attenuated Vibrio anguillarum vaccine induces efficient immunoprotection in tiger puffer (Takifugu rubripes). Vaccine 36, 1460-1466. doi: 10.1016/j.vaccine.2018.01.067

Lu, X. (2010). Development of Multiplex PCR for Simultaneous Microarray Detection of Six Virulence Factors of Vibrio anguillarum and Primary Exploration of Innovative Detection Technologies. Qindao: Ocean University of China.

Ma, Y., Wang, Q., Xu, W., Liu, X., Gao, X., and Zhang, Y. (2017). Stationary phase-dependent accumulation of ectoine is an efficient adaptation strategy in Vibrio anguillarum against cold stress. Microbiol. Res. 205, 8-18. doi: 10.1016/j.micres.2017.08.005

Mcdougald, D., Rice, S. A., Weichart, D., and Kjelleberg, S. (1998). Nonculturability: adaptation or debilitation. FEMS Microbiol. Ecol. 25, 1-9. doi: 10.1111/j.1574-6941.1998.tb00455.x

McGee, K., Hörstedt, P., and Milton, D. L. (1996). Identification and characterization of additional flagellin genes from Vibrio anguillarum. J. Bacteriol. 178, 5188. doi: 10.1128/jb.178.17.5188-5198.1996

Mikkelsen, H., Lund, V., Martinsen, L. C., Gravningen, K., and Schroder, M. B. (2007). Variability among Vibrio anguillarum $\mathrm{O}_{2}$ isolates from atlantic cod (Gadus morhua L.): characterisation and vaccination studies. Aquaculture 266, 16-25. doi: 10.1016/j.aquaculture.2007.02.041

Miyamoto, N., and Eguchi, M. (1997). Response to low osmotic stress in a fish pathogen, Vibrio anguillarum. FEMS Microbiol. Ecol. 22, 225-231. doi: 10.1111/j.1574-6941.1997.tb00374.x

Mortazavi, A., Williams, B. A., Mccue, K., Schaeffer, L., and Wold, B. (2008). Mapping and quantifying mammalian transcriptomes by RNA-Seq. Nat. Methods 5:621. doi: 10.1038/nmeth.1226

Nie, L., Zhou, Q. J., Qiao, Y., and Chen, J. (2017). Interplay between the gut microbiota and immune responses of ayu (Plecoglossus altivelis) during Vibrio anguillarum infection. Fish Shellfish Immunol. 68, 479-487. doi: 10.1016/j.fsi.2017.07.054

Ren, Y., Xue, J., Yang, H., Pan, B., and Bu, W. (2017). Transcriptome analysis of Ruditapes philippinarum hepatopancreas provides insights into immune signaling pathways under Vibrio anguillarum infection. Fish Shellfish Immunol. 64, 14-23. doi: 10.1016/j.fsi.2017.03.005

Rodkhum, C., Hirono, I., Crosa, J. H., and Aoki, T. (2005). Four novel hemolysin genes of Vibrio anguillarum and their virulence to rainbow trout. Microb. Pathogenesis 39, 109-119. doi: 10.1016/j.micpath.2005.06.004

Rodkhum, C., Hirono, I., Crosa, J. H., and Aoki, T. (2006). Multiplex PCR for simultaneous detection of five virulence hemolysin genes in Vibrio anguillarum. J. Microbiol. Methods 65, 612-618. doi: 10.1016/j.mimet.2005.09.009

Romalde, J. L., Barja, J. L., Magariños, B., and Toranzo, A. E. (1994). Starvationsurvival processes of the bacterial fish pathogen Yersinia ruckeri. Syst. Appl. Microbiol. 17, 161-168. doi: 10.1016/S0723-2020(11)80002-0

Saint-Ruf, C., and Matic, I. (2006). Environmental tuning of mutation rates. Environ. Microbiol. 8, 193-199. doi: 10.1046/j.1462-2920.2003. 00397.x-i1

Su, C. P., Jane, W. N., and Wong, H. C. (2013). Changes of ultrastructure and stress tolerance of Vibrio parahaemolyticus upon entering viable but nonculturable state. Int. J. Food Microbiol. 160, 360-366. doi: 10.1016/j.ijfoodmicro.2012.11.012

Su, X., Sun, F., Wang, Y., Hashmi, M. Z., Guo, L., Ding, L., et al. (2015). Identification, characterization and molecular analysis of the viable but nonculturable Rhodococcus biphenylivorans. Sci. Rep. 5, 18590. doi: $10.1038 /$ srep 18590

Svensson, S. L., Pryjma, M., and Gaynor, E. C. (2014). Flagella-mediated adhesion and extracellular dna release contribute to biofilm formation and stress tolerance of Campylobacter jejuni. PLoS ONE 9:e106063. doi: 10.1371/journal.pone.0106063

Toranzo, A. E., Magariños, B., and Romalde, J. L. (2005). A review of the main bacterial fish diseases in mariculture systems. Aquaculture 246, 37-61. doi: 10.1016/j.aquaculture.2005.01.002

Vatsos, I. N., Thompson, K. D., and Adams, A. (2003). Starvation of flavobacterium psychrophilum in broth, stream water and distilled water. Dis. Aquat. Org. 56, 115-126. doi: 10.3354/dao056115 
Wai, S. N., Mizunoe, Y., and Yoshida, S. (1999). How Vibrio cholerae survive during starvation. FEMS Microbiol. Lett. 180, 123-131. doi: 10.1111/j.1574-6968.1999.tb08786.x

Wang, S. Y., Lauritz, J., Jass, J., and Milton, D. L. (2003). Role for the major outer-membrane protein from Vibrio anguillarum in bile resistance and biofilm formation. Microbiology 149, 1061-1071. doi: 10.1099/mic.0. 26032-0

Xu, X., Wu, Q., Zhang, J., Cheng, J., Zhang, S., and Wu, K. (2014). Prevalence, pathogenicity, and serotypes of Vibrio parahaemolyticus in shrimp from Chinese retail markets. Food Control. 46, 81-85. doi: 10.1016/j.foodcont.2014.04.042
Conflict of Interest Statement: The authors declare that the research was conducted in the absence of any commercial or financial relationships that could be construed as a potential conflict of interest.

Copyright (ङ 2018 Gao, Pi, Chen, Li, Liu, Yang, Wei and Zhang. This is an openaccess article distributed under the terms of the Creative Commons Attribution License (CC BY). The use, distribution or reproduction in other forums is permitted, provided the original author(s) and the copyright owner(s) are credited and that the original publication in this journal is cited, in accordance with accepted academic practice. No use, distribution or reproduction is permitted which does not comply with these terms. 